\title{
Response of Watermelon Pulp (Citrullus colocynthoides) to Intercropped Maize (Zea mays L.) With Plants Distributions Under Different Nitrogen Fertilization Levels
}

\author{
A. M. Sheha ${ }^{1}$, Haytham Mostafa El-Shahed ${ }^{2} \&$ Abd El Nabi Hamed Mohamed Diab ${ }^{3}$ \\ ${ }^{1}$ Crop Intensification Research Department, Field Crops Research Institute, Agricultural Research Center, Egypt \\ ${ }^{2}$ Maize Research Department, Field Crops Research Institute, Agricultural Research Center, Egypt \\ ${ }^{3}$ Vegetables Research Department, Horticulture Research Institute, Agricultural Research Center, Egypt \\ Correspondence: A. M. Sheha, Crop Intensification Research Department, Field Crops Research Institute, \\ Agricultural Research Center, Egypt. Tel: 20-100-199-7720. E-mail: dr.ahmedsheha67@yahoo.com
}

Received: June 2, 2020

Accepted: July 2, $2020 \quad$ Online Published: July 15, 2020

doi:10.5539/jas.v12n8p212

URL: https://doi.org/10.5539/jas.v12n8p212

\begin{abstract}
Two field experiments were carried out at the Experimental Farm of Gemmeiza Agriculture Research Station, Agricultural Research Center (ARC), Egypt after 2018 and 2019 summer growing seasons to determine the effect of intercropping pattern of yellow maize hybrid (single cross 168: "SC 168") with watermelon pulp at three plant distributions $(20 \mathrm{~cm}$ between hills and one plant/hill, $40 \mathrm{~cm}$ between hills and two plants/hill and 60 $\mathrm{cm}$ between hills and three plants/hill) and different levels of nitrogen fertilizer $(25,50,75$ and $100 \%$ of the recommended dose " $120 \mathrm{~kg} \mathrm{~N}$ fad $^{-1 "}$ ") as well as their interactions on maize and watermelon pulp growth, yield and its attributes as well as competitive relationships and yield advantages. The experiments were carried out in split-plot design with four replicates. The main-plots were assigned to plant distributions of maize, the sub-plots were allocated to levels of nitrogen fertilizer for maize. The obtained results showed that planting maize plants on one side of terraces of $140 \mathrm{~cm}$ width with $20 \mathrm{~cm}$ between hills and leaving one plant/hill and planting watermelon pulp on the other side of the terraces produced the highest values of plant height, ear height, number of kernels row $^{-1}, 100$-kernel weight and grain yield $\mathrm{fad}^{-1}$, at the same time the lowest values of ear leaf area, ear length, ear diameter and number of rows ear ${ }^{-1}$ of maize as well as the lowest values of growth, yield and its attributes of watermelon pulp during the both seasons. Mineral fertilizing maize plants with $75 \%$ of the recommended dose $(90$ $\mathrm{kg} \mathrm{N} / \mathrm{fad}$ ) and watermelon pulp with the recommended dose produced the highest values of all studied growth characters, yield and its attributes of maize and watermelon pulp in both seasons. The highest values of land equivalent ratio (LER), relative crowding coefficient (RCC), area time equivalent ratio (ATER), land equivalent coefficient (LEC), aggressivity index (AI), monetary advantage index (MAI), actual yield (L.E.) of watermelon, Total income (L.E.) and economic return (L.E.) were obtained from planting maize plants on one side of terraces of $140 \mathrm{~cm}$ width with $60 \mathrm{~cm}$ between hills and leaving three plants/hill and planting watermelon pulp on the other side of the terraces besides fertilizing maize plants with $75 \%$ of the recommended dose $(90 \mathrm{~kg} \mathrm{~N} / \mathrm{fad})$ and watermelon pulp with the recommended dose in both seasons. It can be recommended that planting maize on $60 \mathrm{~cm}$ between hills and leaving three plants/hill and planting watermelon pulp on the other side of the terraces besides fertilizing maize plants with $90 \mathrm{~kg} \mathrm{~N} / \mathrm{fad}$ and watermelon pulp with the recommended dose to obtain the maximum values growth, yield and its attributes of watermelon pulp and competitive relationships and yield advantages of both crops under the climates conditions of Middle Delta, Egypt.
\end{abstract}

Keywords: maize, watermelon pulp, intercropping pattern, plant distributions, nitrogen levels, productivity, competitive relationships, yield advantages

\section{Introduction}

Maize (Zea mays L.) is the most important cereal crops comes the third after wheat and rice in Egypt. Maize is very essential both for the human food or animal feeding and as a common ingredient for several industrial products. Also, maize is used as a feed for livestock whether fresh, silage or grains. Recently, it is necessary to increase maize yield to face the wide gap between production and consumption. Increasing maize production can be achieved by improving cultural practices and planting the promising hybrids. Maize agronomists are continually 
looking for the best ways that help farmers to increase grain yield and net return of the crop, such as suitable intercropping pattern, optimum plant distributions and nitrogen fertilizer levels.

Watermelon pulp (Citrullus Colocynthoides) has been cultivated since the early times in Egypt where it is known as gurma melon. It is the important vegetable crops in Egypt, which can be exported to other countries. Spread cultivation of watermelon pulp in the recent period due to higher income, limited period of their stay in the ground. It has been widely cultivated especially in Northern Regions of Egypt. Its importance is due to its tolerance to drought and salinity, so it's a good crop for the new reclaimed lands. It has been grown as a lone crop or intercropped with some other crops such as maize crop. However, its production has been confined to one variety. The seeds of this locally cultivated variety usually are obtained from ripening fruit.

Intercropping is a common practice in Egypt, but the advantage compared to sole cropping depends on the crop plants and local agro-ecological conditions. Where, Moyin-Jesu (2012) reported that the intercropping systems can increase the land use efficiency and nutrient use efficiency, which resulting in higher yields Ogundari and Ojo (2005).

Appropriate canopy as plant distribution is the key for maximizing maize productivity, which decrease the intra competition among plants, enabling their foliage to receive an appropriate amount of solar radiation and main role in fixing energy along with enough water and nutrients, that ensure a maximum photosynthesis rate, and consequently higher productivity (Duncan, 1984). Plant distribution could be achieved through controlling hill spacing, and number of plants per hill. In this context, Wade et al. (1988) observed that the population of plants per square meter (density) and arrangement of individual plants within a square meter determine nutrient use and grain yield of maize. They added that uneven distribution of plants can reduce grain yield compared to uniform distribution at the same density. Doerge et al. (2002) reported that maize yield can be increased in the perfect equidistant of plant spacing. Schimandeiro et al. (2006) revealed that the irregularity in plant spatial distribution along the rows can reduce the use efficiency of water, light and nutrients by plants, increasing the number of dominated plants in the cultivation. Bruin and Pedersen (2008) indicated that narrowing plant spacing can allow plants to take spatial advantage and increase resource capture and utilization. Sangoi et al. (2012) found that plant arrangement have great importance in the interception and efficiency of conversion of the photosynthetically active radiation intercepted by the canopy into grain production. This effect is more significant in corn than in other Poaceae plants because of its morphological, anatomical and physiological characteristics. Mattera et al. (2013) reported that hill spacing, a practice that determines the spatial distribution of plants, affects canopy structure, light interception, and radiation use efficiency and, consequently, biomass or grain yield. Chim et al. (2014) showed that normalized difference vegetation index (NDVI), intercepted photosynthetically active radiation (IPAR), grain yield and grain $\mathrm{N}$ uptake increased with number of plants per hill and decreased with increasing plant spacing. Silva et al. (2015) showed that as the non-uniformity in plant distribution along the planting row were increased, stalk diameter, 100-grain weight, number of rows/ear, number of kernels/row while ear length decreased. Additionally, linear reductions were observed in maize grain yield with the increase in the coefficient of variation of the spatial distribution of plants along the planting row. Sgarbossa et al. (2018) stated that the increase in the variation of the distribution of maize plants resulted in greater LAI values and more efficient use of solar radiation. Variation of spatial distribution increased the efficient utilization of solar radiation in different ways between plants in the sowing line. This happened due to increase in LAI values and the capture of solar radiation. Shams et al. (2012) found that intercropping maize leaving two plants/hill and adding $120 \mathrm{~kg} \mathrm{~N} / \mathrm{fed}$ in maximum net return and LER and that's when intercropped with peanuts.

Nitrogen has been found to be most important nutrient for maize production, wherever it is affects various physiological and biochemical processes in plant cells that ultimately affect the growth and development of the plant (Shrestha et al., 2018). Maize has been recognized as a heavy feeder and uses more of nitrogen than any other nutrient element. Many reports indicated that nitrogen is considered as one among the most affective factors in increasing growth, yield and yield components of maize crop (Attia et al., 2012; El-Naggar et al., 2012; Hafez \& Abdelaal, 2015; Lomer et al., 2019; Jiang et al., 2019). In spite of mineral fertilizers have a good effect on plant productivity. Studies on maize densities whether maize spacing or number of maize plant/hill which remain after thinning and fertilization rate and the intercropping pattern seemed to be of prime importance in optimizing the association (Hussein, 2005; Sherif et al., 2005).

Therefore, the present study was established to investigate the suitable spatial distribution of maize plants when intercropped with watermelon pulp, as well as the suitable $\mathrm{N}$ fertilizer rates to increase land productivity and farmer profitability. Also, this investigation aimed to study competitive relationships and yield advantages under the climate conditions of El-Gharbia Governorate, Egypt. 


\section{Materials and Methods}

Two field experiments were carried out at the Experimental Farm of Gemmeiza Agriculture Research Station, Agricultural Research Center (ARC), Egypt during 2018 and 2019 summer growing seasons. This investigation aimed to recognize the effect of intercropping pattern of yellow maize hybrid (single cross 168: "SC 168") with watermelon pulp (Local varieties) at three plant distributions and different levels of nitrogen fertilizer as well as their interactions on maize and watermelon pulp growth, yield and its attributes as well as competitive relationships and yield advantages.

\subsection{Studied Factors (Treatments and Experimental Design)}

The experiments were carried out in split-plot design with four replicates. The main-plots were assigned to three

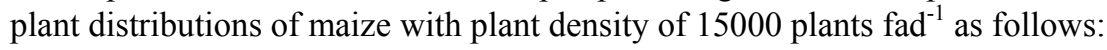

$\mathrm{D}_{1}: 20 \mathrm{~cm}$ between hills (one plant/hill).

$\mathrm{D}_{2}: 40 \mathrm{~cm}$ between hills (two plants/hill).

$\mathrm{D}_{3}: 60 \mathrm{~cm}$ between hills (three plants/hill).

The sub-plots were allocated to four levels of mineral nitrogen fertilizer for maize and the recommended dose for watermelon pulp as follows:

(1) Recommended for watermelon pulp $+1 / 4$ of the recommended for maize (30 kg N/fad.).

(2) Recommended for watermelon pulp $+1 / 2$ of the recommended for maize (60 kg N/fad.)

(3) Recommended for watermelon pulp $+3 / 4$ of the recommended for maize ( $90 \mathrm{~kg} \mathrm{~N} / \mathrm{fad}$.).

(4) Recommended for watermelon pulp $+100 \%$ of the recommended for maize $(120 \mathrm{~kg} \mathrm{~N} / \mathrm{fad}$.).

Nitrogen fertilizer in the form of ammonia sulphate $(20.5 \% \mathrm{~N})$ was applied for maize in two equal portions, one half after thinning (before the first irrigation) and the other half before the second irrigation.

Each experimental basic unit (sub-plot) included four terraces, each of $1.4 \mathrm{~m}$ width and $4.0 \mathrm{~m}$ length, resulted an area of $22.4 \mathrm{~m}^{2}$ (1/400 fad). The preceding winter crop was Egyptian clover (Trifolium alexandrinum L.) and faba bean (Vicia faba L.) in the first and second seasons, respectively.

\subsection{Soil Sampling and Analysis}

The soil samples from the experimental locations were detached from the upper $30 \mathrm{~cm}$ soil surface during land preparation in both 2018 and 2019 seasons. The soil was clay loamy in texture (approximately homogenous) with normal percentage of salinity and its drainage was naturally well. The soil samples of the experimental field in both seasons were laboratory analyzed and their physical and chemical properties are shown in Table 1. Both physical and chemical analysis of the soil was carried out by following the method described by Page (1982). Whereas, N, P and $\mathrm{K}$ elements as well as some micronutrients were determined by applying the procedure documented by (Jackson, 1967).

\subsubsection{Meteorological Data}

Meteorological data of El-Gemmeiza district during the two growing seasons 2018 and 2019 are shown in Table 2. 
Table 1. The mechanical and chemical analysis of the experiments soil is presented in 2018 and 2019 seasons

\begin{tabular}{|c|c|c|}
\hline \multirow{2}{*}{ Determination Mechanical } & First season & Second season \\
\hline & $0-30$ & $0-30$ \\
\hline Clay $\%$ & 57.14 & 55.47 \\
\hline Silt \% & 22.29 & 23.68 \\
\hline Sand $\%$ & 20.57 & 20.85 \\
\hline Texture & Clay & \\
\hline \multicolumn{3}{|l|}{ Chemical analysis } \\
\hline Available N (ppm) & 22.9 & 24.0 \\
\hline Available $\mathrm{P}_{2} \mathrm{O}_{5}(\mathrm{ppm})$ & 9.0 & 11.0 \\
\hline Available $\mathrm{K}_{2} \mathrm{O}$ (ppm) & 350 & 360 \\
\hline $\mathrm{Ec}\left(\mathrm{mmhos} / \mathrm{cm}^{3}\right)$ & 0.8 & 0.9 \\
\hline $\mathrm{pH}$ & 7.40 & 7.3 \\
\hline $\mathrm{CaCO}_{3} \%$ & 2.71 & 3.0 \\
\hline Organic matter $\%$ & 1.0 & 1.2 \\
\hline \multicolumn{3}{|l|}{ Cations (meq/100 g soil) } \\
\hline $\mathrm{Na}^{+}$ & 0.36 & 0.37 \\
\hline $\mathrm{K}^{+}$ & 0.01 & 0.03 \\
\hline $\mathrm{Ca}^{2+}$ & 0.25 & 0.24 \\
\hline $\mathrm{Mg}^{2+}$ & 0.26 & 0.22 \\
\hline \multicolumn{3}{|l|}{ Anions (meq/100 g soil) } \\
\hline $\mathrm{HCO}_{3}^{-}$ & 0.32 & 0.36 \\
\hline $\mathrm{Cl}^{-}$ & 0.36 & 0.28 \\
\hline $\mathrm{SO}_{4}$ & 0.20 & 0.22 \\
\hline
\end{tabular}

Table 2. Monthly maximum and minimum temperature $\left({ }^{\circ} \mathrm{C}\right)$ and relative humidity $(\%)^{*}$ at the experimental site during the two growing seasons

\begin{tabular}{|c|c|c|c|c|c|c|c|c|}
\hline \multirow{3}{*}{ Months } & \multicolumn{4}{|c|}{ Temperature $\left({ }^{\circ} \mathbf{C}\right)$} & \multicolumn{4}{|c|}{ Relative humidity (\%) } \\
\hline & \multicolumn{2}{|c|}{2018} & \multicolumn{2}{|c|}{2019} & \multicolumn{2}{|c|}{2018} & \multicolumn{2}{|c|}{2019} \\
\hline & Max. & Min. & Max. & Min. & Max. & Min. & Max. & Min. \\
\hline April & 30.2 & 27.0 & 34.9 & 30.4 & 83.0 & 41.5 & 84.2 & 40.0 \\
\hline May & 32.4 & 27.9 & 35.2 & 31.4 & 82.4 & 40.6 & 85.2 & 40.5 \\
\hline June & 33.4 & 28.0 & 36.2 & 30.6 & 84.5 & 42.4 & 86.7 & 42.7 \\
\hline July & 36.0 & 26.2 & 38.3 & 31.5 & 84.0 & 42.0 & 85.2 & 43.08 \\
\hline August & 35.3 & 24.5 & 37.7 & 25.9 & 84.4 & 41.5 & 84.9 & 42.3 \\
\hline September & 34.0 & 24.8 & 35.02 & 26.0 & 83.7 & 41.9 & 85.6 & 42.5 \\
\hline October & 33.8 & 22.4 & 34.10 & 25.3 & 83.6 & 40.6 & 83.8 & 41.2 \\
\hline
\end{tabular}

Note. ${ }^{*}$ The source of this data is Ministry of Agriculture and Reclamation of Soils, Agriculture Research Center (ARC), Central Management of Agriculture Guideline, Bulletin of Agricultural Meteorological Data.

\subsection{Cultural Practices}

In addition to, the individual cultivation of both crops was done, local variety watermelon pulp was planted on terraces at a distance of $25 \mathrm{~cm}$ apart (one plant/ hill) on $10^{\text {th }}$ and $12^{\text {th }}$ May in the first and second seasons, respectively. Yellow maize hybrid (SC 168) was planted on the other side of the watermelon pulp terraces with aforementioned plant distributions on $6^{\text {th }}$ and $9^{\text {th }}$ June in the first and second seasons, respectively. Ordinary calcium superphosphate fertilizer $\left(15.5 \% \mathrm{P}_{2} \mathrm{O}_{5}\right)$ was applied as one dose for all plots during soil preparation at the rate of $150 \mathrm{~kg} /$ fad. Potassium sulphate $\left(48 \% \mathrm{~K}_{2} \mathrm{O}\right)$ at the rate of $50 \mathrm{~kg} / \mathrm{fad}$ was applied for all plots before the second irrigation of the maize. Nitrogen fertilizer in the form of ammonia sulphate $(20.5 \% \mathrm{~N})$ was applied for watermelon pulp in three equal doses before the first irrigation, at flowering and during the contract. The other agricultural practices for watermelon pulp and maize were kept the same as normally practiced according to the recommendations of Field Crops Research Institute, except for the factors under study. 
Harvesting was done for watermelon pulp on $1^{\text {st }}$ and $8^{\text {th }}$ September in both seasons. Also, the maize was hybrid harvested on $15-20^{\text {th }}$ October in both seasons.

\subsection{Data Recorded}

At harvest time, random samples of ten guarded plants were taken from each sub-plot to determine the following characters:

\subsubsection{Maize Traits}

Plant height $(\mathrm{cm})$, ear height $(\mathrm{cm})$, ear leaf area (ELA), ear length $(\mathrm{cm})$, ear diameter $(\mathrm{cm})$, number of rows ear ${ }^{-1}$, number of kernels row $^{-1}, 100$-kernel weight $(\mathrm{g})$ and grain yield $\left(\operatorname{ardab} \mathrm{fad}^{-1}\right)$. Grain yield was adjusted to moisture content of $15.5 \%$ and transformed to ardab per faddan (one $\operatorname{ardab}=140 \mathrm{~kg}$ and one faddan $=4200 \mathrm{~m}^{2}$ ).

\subsubsection{Watermelon Pulp Traits}

Number of fruits plot ${ }^{-1}$, number of seeds fruits ${ }^{-1}$, seeds weight fruits ${ }^{-1}, 100$-seed weight $(\mathrm{g})$, seed weight plot $^{-1}$ and seeds weight $\mathrm{fad}^{-1}$.

\subsection{Competitive Relationships and Yield Advantages}

The following competitive relationships and yield advantages were calculated:

(1) Land equivalent ratio (LER): It was determined according to the following formula described by Willey and Rao (1980):

$$
\mathrm{LER}=\frac{\mathrm{Yab}}{\mathrm{Yaa}}+\frac{\mathrm{Yba}}{\mathrm{Ybb}}
$$

Where, Yaa and Ybb were pure stand of crop, a (watermelon) and b (maize), respectively. Yab is mixture yield of a crop and $\mathrm{Yba}$ is mixture yield $\mathrm{b}$ crop.

(2) Relative crowding coefficient (RCC) or K: It was calculated according to De-Wit (1960) as follows:

$$
\begin{gathered}
\mathrm{K}=\mathrm{Kab} \times \mathrm{Kba} \\
\mathrm{Kab}=\frac{\mathrm{Yab} \times \mathrm{Zba}}{(\mathrm{Yaa}-\mathrm{Yab}) \mathrm{Zab}} ; \mathrm{Kba}=\frac{\mathrm{Yba} \times \mathrm{Zab}}{(\mathrm{Ybb}-\mathrm{Yba}) \mathrm{Zba}}
\end{gathered}
$$

Where, a (watermelon) and $b$ (maize) respectively. $b$ is percentage of the area occupied by watermelon and Zba is percentage of the area occupied by maize.

(3) Area time equivalent ratio (ATER): The ratio of number of hectare-days required in monoculture to the number of hectare-days used in the intercrop to produce identical quantities of each component was calculated according to Hiebsch and Mc-Collum (1987) as follows:

$$
\mathrm{ATER}=(\mathrm{RYa} \times \mathrm{ta})+(\mathrm{RYb} \times \mathrm{tb}) / \mathrm{T} \text { or ATER }=\left(\frac{\mathrm{Yab}}{\mathrm{Ya}} \times \mathrm{ta}\right)+\left(\frac{\mathrm{Yba}}{\mathrm{Ybb}} \times \mathrm{tb}\right) / \mathrm{T}
$$

Where, $\mathrm{RY}=$ Relative yield of crop a (watermelon) or crop $\mathrm{b}$ (maize). i.e., yield of intercrop/yield of main crop, $\mathrm{t}$ $=$ duration (days) for species $\mathrm{a}$ or $\mathrm{b}$ and $\mathrm{T}=$ duration (days) of the intercropping system.

(4) Land equivalent coefficient (LEC): It is a measure of interaction concerned with the strength of relationship and was calculated according to Adetiloye et al. (1983) as following:

$$
\mathrm{LEC}=\mathrm{La} \times \mathrm{Lb}
$$

Where, La $=$ LER of crop a (watermelon) and Lb $=$ LER of crop $b$ (maize).

(5) Aggressivity (Ag): It was calculated according to Mc-Gilchrist (1965) as the following formula:

$$
\mathrm{Aga}=\frac{\mathrm{Yab}}{\mathrm{Yaa} \times \mathrm{Zab}}-\frac{\mathrm{Yba}}{\mathrm{Ybb} \times \mathrm{Zba}} ; \mathrm{Agb}=\frac{\mathrm{Yab}}{\mathrm{Yaa} \times \mathrm{Zab}}-\frac{\mathrm{Yba}}{\mathrm{Ybb} \times \mathrm{Zba}}
$$

Where, Aga = Aggressivity value for the component a (watermelon); Agb = Aggressivity value for the component $\mathrm{b}$ (maize); Yab is intercrop yield of watermelon, Zab is percentage of the area occupied by watermelon and $\mathrm{Zba}$ is percentage of the area occupied by maize.

(6) Monetary advantage index (MAI) fad $^{-1}$ : Suggests that the economic assessment should be in terms of the value of land saved, this could probably be most assessed on the basis of the rentable value of this land. MAI was calculated according to the formula, suggested by Willey (1979).

$$
\mathrm{MAI}=\frac{\text { Value of combined intercrop } \times(\mathrm{LER}-1)}{\operatorname{LER}}
$$


(7) Economic evaluations: Gross return from each treatment was calculated in Egyptian pounds (LE):

$$
\begin{aligned}
& \text { Watermelon seed }(\mathrm{kg} / \mathrm{fad} .)=25 \mathrm{LE} \\
& \text { Maize grains }(\mathrm{ard} / \mathrm{fad} .)=500 \mathrm{LE}
\end{aligned}
$$

In 2018 and 2019 seasons, market price of the yield was determined according to the Ministry of Agriculture and Land Reclamation, Economic Affairs Sector, Agricultural Statistics.

\subsection{Statistical Analysis}

The obtained data were statistically analyzed according to the technique of analysis of variance (ANOVA) for the split-plot design as published by K. N. Gomez and A. A. Gomez (1984) using "MSTAT-C" computer software package. Means of treatments were compared using Duncan's multiple range tests at $5 \%$ level of probability as described by Duncan (1955).

\section{Results and Discussion}

\subsection{Maize Growth, Yield and Its Attributes}

The obtained data presented in Tables 3 and 4 showed that studied plant distributions of maize intercropped with watermelon pulp exhibited significant effects on maize growth, yield and its attributes, i.e., plant height, ear height, ear leaf area, ear length and ear diameter, number of rows ear ${ }^{-1}$, number of kernels row $^{-1}, 100$-kernel weight and grain yield fad ${ }^{-1}$ in both seasons. Planting maize plants on one side of terraces of $140 \mathrm{~cm}$ width with $20 \mathrm{~cm}$ between hills and leaving one plant/hill attained the highest values of plant height, ear height, number of kernels row ${ }^{-1}$, 100-kernel weight and grain yield $\mathrm{fad}^{-1}$ at the same time the lowest values of ear leaf area, ear length and ear diameter and number of rows ear ${ }^{-1}$ of maize during the two summer seasons of 2018 and 2019. However, planting on one side of terraces of $140 \mathrm{~cm}$ width with $60 \mathrm{~cm}$ between hills and leaving three plants/hill resulted in the highest values of ear leaf area, ear length and ear diameter and number of rows ear ${ }^{-1}$ simultaneously the lowest values of plant height, ear height, number of kernels row $^{-1}, 100$-kernel weight and grain yield fad ${ }^{-1}$ of maize during the two summer seasons of 2018 and 2019. Grain yield fad ${ }^{-1}$ increased markedly by 10.55 and $16.39 \%$, in the first season, corresponding to 10.46 and $18.51 \%$, in the second seasons when $\mathrm{D}_{1}(20 \mathrm{~cm}$ between hills and one plant/hill) was used, compared with $\mathrm{D}_{2}\left(40 \mathrm{~cm}\right.$ between hills and two plants/hill) and $\mathrm{D}_{3}(60 \mathrm{~cm}$ between hills and three plants/hill), respectively. The increment in grain yield fad ${ }^{-1}$ associated with $\mathrm{D}_{1}$ plant distribution may be due to that pattern ensured better conditions concerning foliage light interception and decreased the intra-specific competition between maize plants for growth factors, which positively contributed to higher photosynthesis rate and hence higher values of number of kernels row $^{-1}$ and 100-kernel weight, which participated in increasing grain yield $\mathrm{fad}^{-1}$. These results are in harmony with those reported by Doerge et al. (2002), Chim et al. (2014), and Silva et al. (2015).

The data revealed in Tables 3 and 4 demonstrated that the effect of nitrogen fertilizer levels on maize growth, yield and its attributes (plant height, ear height, ear leaf area, ear length and ear diameter, number of rows ear ${ }^{-1}$, number of kernels row ${ }^{-1}, 100$-kernel weight and grain yield $\mathrm{fad}^{-1}$ ) were significant in the two growing seasons. It can be stated that all studied growth, yield and its attributes significantly increased as a result of increasing mineral nitrogen fertilizer for maize $25 \%\left(30 \mathrm{~kg} \mathrm{~N}^{-1}\right)$ to $50 \%\left(60 \mathrm{~kg} \mathrm{~N}^{-1}\right)$ and $75 \%\left(90 \mathrm{~kg} \mathrm{~N} \mathrm{fad} \mathrm{da}^{-1}\right)$ of the recommended dose and the differences among them were significant in both seasons. Thus, mineral fertilizing maize plants with $75 \%$ of the recommended dose $\left(90 \mathrm{~kg} \mathrm{~N} \mathrm{fad}^{-1}\right)$ produced the highest values of all studied growth, yield and its attributes of maize in both seasons. While, mineral fertilizing maize plants with $100 \%$ of the recommended dose $\left(120 \mathrm{~kg} \mathrm{~N} f a d^{-1}\right)$ came in the second rank after fertilizing with $75 \%$ of the recommended dose with respect to these characters in both seasons. On the other side, the lowest values of growth, yield and its attributes of maize were resulted from fertilizing maize plants with the lowest nitrogen fertilizer level $(25 \%$ of the recommended dose, i.e., $30 \mathrm{~kg} \mathrm{~N}$ fad $^{-1}$ ) in both seasons. The increases in growth, yield and its attributes of maize crop as a result of increasing nitrogen fertilizer level up to $90 \mathrm{~kg} \mathrm{~N} /$ fad can be ascribed to the role of $\mathrm{N}$ element in monitoring of many basic physiological processes in maize plants such as photosynthetic rate and the accumulation of more metabolites partitioned to plant organs, reflecting therefore better growth of maize. Also, the positive response of maize plants and in turn the studied characters to the nitrogen levels applied could be attributed to the reduction of the organic matter and available $\mathrm{N}$ in the experimental soils of this study as shown in Table 1. Comparable results were in coincidence with those stated by El-Naggar et al. (2012), Hafez and Abdelaal (2015), Lomer et al. (2019), and Jiang et al. (2019).

The interaction between plant distributions and nitrogen fertilizer levels illustrate significant effect on maize growth, yield and its attributes (plant height, ear height, ear leaf area, ear length and ear diameter, number of rows ear $^{-1}$, number of kernels row ${ }^{-1}, 100$-kernel weight and grain yield fad $^{-1}$ ) in both seasons (Tables 3 and 4 ). The 
maximum values of plant height, ear height and number of kernels row ${ }^{-1}$ were obtained from planting maize plants on one side of terraces of $140 \mathrm{~cm}$ width with $20 \mathrm{~cm}$ between hills and leaving one plant/hill in addition fertilizing with $75 \%$ of the recommended dose $\left(90 \mathrm{~kg} \mathrm{~N} \mathrm{fad}^{-1}\right)$ in both seasons. However, the maximum values of 100-kernel weight and grain yield $\mathrm{fad}^{-1}$ were obtained from planting maize plants on one side of terraces of $140 \mathrm{~cm}$ width with $20 \mathrm{~cm}$ between hills and leaving one plant/hill in addition fertilizing with $100 \%$ of the recommended dose (120 $\mathrm{kg} \mathrm{N} \mathrm{fad}^{-1}$ ) in both seasons. Though, the maximum values of ear leaf area, ear length, ear diameter and number of rows ear ${ }^{-1}$ were resulted from planting maize plants on one side of terraces of $140 \mathrm{~cm}$ width with $60 \mathrm{~cm}$ between hills and leaving three plants/hill additionally fertilizing with $75 \%$ of the recommended dose $\left(90 \mathrm{~kg} \mathrm{~N} \mathrm{fad}^{-1}\right)$ in both seasons. While, the lowest values of plant height, ear height, number of kernels row ${ }^{-1}, 100$-kernel weight and grain yield $\mathrm{fad}^{-1}$ were obtained from planting maize plants on one side of terraces of $140 \mathrm{~cm}$ width with $60 \mathrm{~cm}$ between hills and leaving three plant/hill in addition fertilizing with $25 \%$ of the recommended dose $\left(30 \mathrm{~kg} \mathrm{~N} \mathrm{fad}^{-1}\right)$ in both seasons. Nevertheless, the lowest values of ear leaf area, ear length, ear diameter and number of rows ear ${ }^{-1}$ were resulted from planting maize plants on one side of terraces of $140 \mathrm{~cm}$ width with $20 \mathrm{~cm}$ between hills and leaving one plant/hill additionally fertilizing with $25 \%$ of the recommended dose $\left(30 \mathrm{~kg} \mathrm{~N} \mathrm{~d}^{-1}\right)$ in both seasons.

Table 3. Effect of plant distributions and different levels of nitrogen fertilizer as well as their interactions on plant height, ear height, ear leaf area, ear length and ear diameter of maize during the two summer seasons 2018 and 2019

\begin{tabular}{|c|c|c|c|c|c|c|c|c|c|c|c|}
\hline \multirow{2}{*}{\multicolumn{2}{|c|}{$\begin{array}{l}\text { Characters } \\
\text { Treatments }\end{array}$}} & \multicolumn{2}{|c|}{ Plant height (cm) } & \multicolumn{2}{|c|}{ Ear height (cm) } & \multicolumn{2}{|c|}{ Ear leaf area $\left(\mathrm{cm}^{2}\right)$} & \multicolumn{2}{|c|}{ Ear length (cm) } & \multicolumn{2}{|c|}{ Ear diameter $(\mathrm{cm})$} \\
\hline & & 2018 & 2019 & 2018 & 2019 & 2018 & 2019 & 2018 & 2019 & 2018 & 2019 \\
\hline \multicolumn{12}{|c|}{ Plant distributions } \\
\hline \multicolumn{2}{|c|}{$D_{1}-20 \mathrm{~cm} \& 1$ plant } & $230.49 \mathrm{a}$ & $219.17 \mathrm{a}$ & $132.25 \mathrm{a}$ & $126.68 \mathrm{a}$ & $515.00 \mathrm{c}$ & $569.20 \mathrm{c}$ & $16.94 \mathrm{~b}$ & $17.91 \mathrm{~b}$ & $3.35 \mathrm{c}$ & $3.63 \mathrm{c}$ \\
\hline \multicolumn{2}{|c|}{$D_{2}-40 \mathrm{~cm} \& 2$ plants } & $226.28 \mathrm{a}$ & $210.17 b$ & $126.50 \mathrm{~b}$ & $122.83 \mathrm{~b}$ & $673.30 \mathrm{~b}$ & $645.00 \mathrm{~b}$ & $17.44 \mathrm{~b}$ & $17.97 \mathrm{~b}$ & $4.50 \mathrm{~b}$ & $4.77 \mathrm{~b}$ \\
\hline \multicolumn{2}{|c|}{$D_{3}-60 \mathrm{~cm} \& 3$ plants } & $221.50 \mathrm{~b}$ & $202.08 \mathrm{c}$ & $122.80 \mathrm{c}$ & $116.35 \mathrm{c}$ & $703.30 \mathrm{a}$ & $738.30 \mathrm{a}$ & $19.82 \mathrm{a}$ & $20.79 \mathrm{a}$ & $4.97 \mathrm{a}$ & $5.20 \mathrm{a}$ \\
\hline \multicolumn{12}{|c|}{ Nitrogen fertilizer as ratio of the recommended dose } \\
\hline \multicolumn{2}{|c|}{$25 \%$} & $212.57 \mathrm{~d}$ & $190.11 \mathrm{~d}$ & $119.89 \mathrm{~d}$ & $115.41 \mathrm{~d}$ & $541.10 \mathrm{~d}$ & $585.60 \mathrm{c}$ & $16.87 \mathrm{~d}$ & $17.26 \mathrm{~d}$ & $3.88 \mathrm{~b}$ & $4.11 \mathrm{c}$ \\
\hline \multicolumn{2}{|c|}{$50 \%$} & $216.49 \mathrm{c}$ & $201.33 \mathrm{c}$ & $124.99 \mathrm{c}$ & $117.39 \mathrm{c}$ & $621.10 \mathrm{~b}$ & $632.20 \mathrm{~b}$ & $17.79 \mathrm{c}$ & $18.49 \mathrm{c}$ & $4.31 \mathrm{a}$ & $4.29 \mathrm{~b}$ \\
\hline \multicolumn{2}{|c|}{$75 \%$} & $254.87 \mathrm{a}$ & $242.00 \mathrm{a}$ & $135.54 \mathrm{a}$ & $132.48 \mathrm{a}$ & $762.20 \mathrm{a}$ & $734.40 \mathrm{a}$ & $19.20 \mathrm{a}$ & $20.22 \mathrm{a}$ & $4.47 \mathrm{a}$ & $5.45 \mathrm{a}$ \\
\hline \multicolumn{2}{|c|}{$100 \%$} & $220.44 \mathrm{~b}$ & $208.44 \mathrm{~b}$ & $128.31 \mathrm{~b}$ & $122.53 \mathrm{~b}$ & $597.80 \mathrm{c}$ & $651.10 \mathrm{~b}$ & $18.41 \mathrm{~b}$ & $19.59 \mathrm{~b}$ & $4.43 \mathrm{a}$ & $4.28 \mathrm{~b}$ \\
\hline \multicolumn{12}{|c|}{ Interaction } \\
\hline \multirow{4}{*}{$\mathbf{D}_{1}$} & $25 \%$ & $217.17 \mathrm{e} \mathrm{g}$ & $192.67 \mathrm{~g}$ & $126.00 \mathrm{e}$ & $120.67 f$ & $450.00 \mathrm{i}$ & $506.70 \mathrm{~g}$ & $15.40 \mathrm{f}$ & $15.82 \mathrm{i}$ & $3.13 \mathrm{e}$ & $3.22 \mathrm{j}$ \\
\hline & $50 \%$ & $219.90 \mathrm{c} \mathrm{e}$ & $206.00 \mathrm{e}$ & $128.00 \mathrm{~d}$ & $122.53 \mathrm{e}$ & $510.00 \mathrm{~h}$ & $556.70 \mathrm{f}$ & $16.38 \mathrm{e}$ & $17.71 \mathrm{fh}$ & $3.24 \mathrm{e}$ & $3.35 \mathrm{i}$ \\
\hline & $75 \%$ & $260.97 \mathrm{a}$ & $246.00 \mathrm{a}$ & $141.00 \mathrm{a}$ & $137.67 \mathrm{a}$ & $580.00 \mathrm{fg}$ & $643.30 \mathrm{e}$ & $17.60 \mathrm{~d}$ & 18.60 ef & $3.43 \mathrm{de}$ & $3.56 \mathrm{~h}$ \\
\hline & $100 \%$ & $223.93 \mathrm{~cd}$ & $232.00 \mathrm{c}$ & $134.00 \mathrm{~b}$ & $125.83 \mathrm{~d}$ & $520.00 \mathrm{~h}$ & $570.00 \mathrm{f}$ & $18.36 \mathrm{c}$ & $19.74 \mathrm{~cd}$ & $3.60 \mathrm{~d}$ & $3.39 \mathrm{i}$ \\
\hline \multirow{4}{*}{$\mathbf{D}_{2}$} & $25 \%$ & $213.53 \mathrm{fh}$ & $189.67 \mathrm{~h}$ & $117.10 \mathrm{~g}$ & $117.40 \mathrm{~h}$ & $576.67 \mathrm{~g}$ & $570.00 \mathrm{f}$ & $16.60 \mathrm{e}$ & $16.88 \mathrm{~h}$ & $4.35 \mathrm{~b} \mathrm{c}$ & $4.31 \mathrm{j}$ \\
\hline & $50 \%$ & $218.60 \mathrm{df}$ & $199.00 \mathrm{f}$ & $126.00 \mathrm{e}$ & $119.40 \mathrm{~g}$ & $650.00 \mathrm{~d}$ & $613.30 \mathrm{e}$ & $17.63 \mathrm{~d}$ & $17.26 \mathrm{~g} \mathrm{~h}$ & $4.51 \mathrm{~b}$ & $4.45 \mathrm{f}$ \\
\hline & $75 \%$ & $247.93 \mathrm{~b}$ & $240.00 \mathrm{~b}$ & $133.63 \mathrm{~b} \mathrm{c}$ & $131.77 \mathrm{~b}$ & $836.70 \mathrm{~b}$ & $760.00 \mathrm{~b}$ & $18.37 \mathrm{c}$ & $19.71 \mathrm{~cd}$ & $4.64 \mathrm{~b}$ & $4.74 \mathrm{~d}$ \\
\hline & $100 \%$ & $225.07 \mathrm{c}$ & $212.00 \mathrm{~d}$ & $129.27 \mathrm{~d}$ & $122.77 \mathrm{e}$ & $630.00 \mathrm{e}$ & $636.70 \mathrm{e}$ & $17.17 \mathrm{~d}$ & $17.80 \mathrm{fg}$ & $4.49 \mathrm{~b}$ & $4.56 \mathrm{e}$ \\
\hline \multirow{4}{*}{$\mathbf{D}_{3}$} & $25 \%$ & $207.00 \mathrm{i}$ & $188.00 \mathrm{~h}$ & $116.57 \mathrm{~g}$ & $108.17 \mathrm{j}$ & $596.70 \mathrm{f}$ & $680.00 \mathrm{~d}$ & $18.61 \mathrm{c}$ & $19.07 \mathrm{de}$ & $4.17 \mathrm{c}$ & $4.80 \mathrm{~d}$ \\
\hline & $50 \%$ & $210.97 \mathrm{~h} \mathrm{i}$ & $199.00 \mathrm{f}$ & $120.97 \mathrm{f}$ & $110.23 \mathrm{i}$ & $703.30 \mathrm{c}$ & $726.70 \mathrm{c}$ & $19.36 \mathrm{~b}$ & $20.51 \mathrm{~b} \mathrm{c}$ & $5.16 \mathrm{a}$ & $5.06 \mathrm{~b}$ \\
\hline & $75 \%$ & $255.70 \mathrm{a}$ & $240.00 \mathrm{~b}$ & $132.00 \mathrm{c}$ & $128.00 \mathrm{c}$ & $870.00 \mathrm{a}$ & $800.00 \mathrm{a}$ & $21.62 \mathrm{a}$ & $22.36 \mathrm{a}$ & $5.35 \mathrm{a}$ & $5.38 \mathrm{a}$ \\
\hline & $100 \%$ & $212.33 \mathrm{~g} \mathrm{i}$ & $181.33 \mathrm{i}$ & $121.67 \mathrm{f}$ & $119.00 \mathrm{~g}$ & $643.30 \mathrm{~d} \mathrm{e}$ & $746.70 \mathrm{bc}$ & $19.71 \mathrm{~b}$ & $21.22 \mathrm{~b}$ & $5.19 \mathrm{a}$ & $4.89 \mathrm{c}$ \\
\hline \multicolumn{2}{|c|}{ Solid } & 270.00 & 260.00 & 155.00 & 140.00 & 658.41 & 689.47 & 23.20 & 22.80 & 5.41 & 5.00 \\
\hline
\end{tabular}


Table 4. Effect of plant distributions and different levels of nitrogen fertilizer as well as their interactions on number of rows ear ${ }^{-1}$, number of kernels row $^{-1}, 100$-kernel weight and grain yield/fad of maize during the two summer seasons 2018 and 2019

\begin{tabular}{|c|c|c|c|c|c|c|c|c|c|}
\hline \multirow{2}{*}{\multicolumn{2}{|c|}{$\begin{array}{l}\text { Characters } \\
\text { Treatments }\end{array}$}} & \multicolumn{2}{|c|}{ No. of rows ear ${ }^{-1}$} & \multicolumn{2}{|c|}{ No. of kernels row ${ }^{-1}$} & \multicolumn{2}{|c|}{ 100-kernel weight (g) } & \multicolumn{2}{|c|}{ Grain yield (ardab fad $^{-1}$ ) } \\
\hline & & 2018 & 2019 & 2018 & 2019 & 2018 & 2019 & 2018 & 2019 \\
\hline \multicolumn{10}{|c|}{ Plant distributions: } \\
\hline$D_{1}-20 c$ & n \& 1 plant & $14.57 \mathrm{c}$ & $15.24 \mathrm{~b}$ & $47.30 \mathrm{a}$ & $47.01 \mathrm{a}$ & $35.33 \mathrm{a}$ & $36.46 \mathrm{a}$ & $14.98 \mathrm{a}$ & $16.58 \mathrm{a}$ \\
\hline$D_{2}-40 c$ & n \& 2 plants & $15.73 b$ & $15.42 \mathrm{~b}$ & $43.92 \mathrm{~b}$ & $45.47 \mathrm{~b}$ & $30.94 \mathrm{~b}$ & $29.67 \mathrm{~b}$ & $13.55 b$ & $15.01 \mathrm{~b}$ \\
\hline$D_{3}-60 c$ & $n \& 3$ plants & $16.80 \mathrm{a}$ & $17.83 \mathrm{a}$ & $41.90 \mathrm{c}$ & $40.49 \mathrm{c}$ & $27.06 \mathrm{c}$ & $27.69 \mathrm{~b}$ & $12.87 \mathrm{~b}$ & $13.99 \mathrm{~b}$ \\
\hline \multicolumn{10}{|c|}{ Nitrogen fertilizer as ratio of the recommended dose: } \\
\hline $25 \%$ & & $14.68 \mathrm{c}$ & $15.23 \mathrm{c}$ & $40.18 \mathrm{~d}$ & $42.01 \mathrm{~d}$ & $27.91 \mathrm{c}$ & $27.82 \mathrm{c}$ & $12.19 \mathrm{c}$ & $12.62 \mathrm{c}$ \\
\hline $50 \%$ & & $15.74 \mathrm{~b}$ & $15.92 \mathrm{~b}$ & $43.19 \mathrm{c}$ & $44.24 \mathrm{c}$ & $29.93 \mathrm{~b}$ & $30.04 \mathrm{~b}$ & $13.29 \mathrm{~b}$ & $14.40 \mathrm{~b}$ \\
\hline $75 \%$ & & $16.41 \mathrm{a}$ & $17.39 \mathrm{a}$ & $48.37 \mathrm{a}$ & $46.23 \mathrm{a}$ & $33.30 \mathrm{a}$ & $33.63 \mathrm{a}$ & $15.08 \mathrm{a}$ & $17.03 \mathrm{a}$ \\
\hline $100 \%$ & & $15.96 \mathrm{~b}$ & $16.10 \mathrm{~b}$ & $45.77 \mathrm{~b}$ & $44.80 \mathrm{~b}$ & $33.30 \mathrm{a}$ & $33.59 \mathrm{a}$ & $14.65 \mathrm{a}$ & $16.74 \mathrm{a}$ \\
\hline \multicolumn{10}{|c|}{ Interaction: } \\
\hline \multirow{4}{*}{$\mathbf{D}_{1}$} & $25 \%$ & $13.53 \mathrm{~h}$ & $14.27 \mathrm{j}$ & $43.37 \mathrm{e}$ & $45.53 \mathrm{~d}$ & $32.13 \mathrm{~d}$ & $32.73 \mathrm{~d}$ & $13.34 \mathrm{~d}$ & $13.74 \mathrm{f} \mathrm{g}$ \\
\hline & $50 \%$ & $14.47 \mathrm{~g}$ & $14.53 \mathrm{j}$ & $46.73 \mathrm{c}$ & $46.40 \mathrm{c}$ & $33.60 \mathrm{c}$ & $34.67 \mathrm{c}$ & $14.46 \mathrm{c}$ & $15.55 \mathrm{~d} \mathrm{e}$ \\
\hline & $75 \%$ & $15.53 \mathrm{f}$ & $16.70 \mathrm{~d}$ & $50.77 \mathrm{a}$ & $48.67 \mathrm{a}$ & $36.53 \mathrm{~b}$ & $38.50 \mathrm{~b}$ & $15.71 \mathrm{ab}$ & $17.83 \mathrm{~b}$ \\
\hline & $100 \%$ & $14.73 \mathrm{~g}$ & $15.47 \mathrm{~g} \mathrm{~h}$ & $48.33 \mathrm{~b}$ & $47.43 \mathrm{~b}$ & $39.07 \mathrm{a}$ & $39.93 \mathrm{a}$ & $16.43 \mathrm{a}$ & $19.21 \mathrm{a}$ \\
\hline \multirow{4}{*}{$\mathbf{D}_{2}$} & $25 \%$ & $14.40 \mathrm{~g}$ & $15.07 \mathrm{~h} \mathrm{i}$ & $40.73 \mathrm{f}$ & $43.40 \mathrm{f}$ & $27.20 \mathrm{f}$ & $26.20 \mathrm{~g}$ & $11.92 \mathrm{f} \mathrm{g}$ & $12.77 \mathrm{~h}$ \\
\hline & $50 \%$ & $16.00 \mathrm{e}$ & $15.87 \mathrm{fg}$ & $41.80 \mathrm{f}$ & $44.57 \mathrm{e}$ & $29.53 \mathrm{e}$ & $28.17 \mathrm{f}$ & $12.90 \mathrm{~d} \mathrm{e}$ & 14.59 e f \\
\hline & $75 \%$ & $16.43 \mathrm{c} \mathrm{d}$ & $16.10 \mathrm{ef}$ & $48.23 \mathrm{~b}$ & $47.67 \mathrm{~b}$ & $33.87 \mathrm{c}$ & $31.97 \mathrm{~d}$ & $14.99 \mathrm{~b} \mathrm{c}$ & $16.54 \mathrm{c}$ \\
\hline & $100 \%$ & $16.07 \mathrm{~d} \mathrm{e}$ & $14.63 \mathrm{i} \mathrm{j}$ & $44.93 \mathrm{~d}$ & $46.23 \mathrm{c}$ & $33.17 \mathrm{~cd}$ & $32.33 \mathrm{~d}$ & $14.38 \mathrm{c}$ & $16.15 \mathrm{~cd}$ \\
\hline \multirow{4}{*}{$\mathbf{D}_{3}$} & $25 \%$ & $16.10 \mathrm{~d} \mathrm{e}$ & $16.37 \mathrm{~d} \mathrm{e}$ & $36.43 \mathrm{~g}$ & $37.10 \mathrm{j}$ & $24.40 \mathrm{~g}$ & $24.53 \mathrm{~h}$ & $11.30 \mathrm{~g}$ & $11.34 \mathrm{i}$ \\
\hline & $50 \%$ & $16.77 \mathrm{~b} \mathrm{c}$ & $17.37 \mathrm{c}$ & $41.03 \mathrm{f}$ & $41.77 \mathrm{~h}$ & $26.67 \mathrm{f}$ & $27.30 \mathrm{fg}$ & $12.51 \mathrm{e} \mathrm{f}$ & $13.07 \mathrm{~g} \mathrm{~h}$ \\
\hline & $75 \%$ & $17.27 \mathrm{a}$ & $19.37 \mathrm{a}$ & $46.10 \mathrm{c}$ & $42.37 \mathrm{~g}$ & $29.50 \mathrm{e}$ & $30.43 \mathrm{e}$ & $14.54 \mathrm{c}$ & $16.70 \mathrm{c}$ \\
\hline & $100 \%$ & $17.07 \mathrm{ab}$ & $18.20 \mathrm{~b}$ & $44.03 \mathrm{de}$ & $40.73 \mathrm{i}$ & $27.60 \mathrm{f}$ & $28.50 \mathrm{f}$ & $13.14 \mathrm{~d} \mathrm{e}$ & $14.87 \mathrm{e}$ \\
\hline \multicolumn{2}{|l|}{ Solid } & 17.81 & 19.45 & 48.38 & 48.75 & 41.20 & 39.00 & 27.50 & 28.00 \\
\hline
\end{tabular}

\subsection{Watermelon Pulp Traits}

The studied plant distribution of maize intercropped with watermelon pulp excreted significant effects on watermelon pulp growth, yield and its attributes, i.e., number of fruits plots $^{-1}$, number of seeds fruit ${ }^{-1}$, seeds weight fruit $^{-1}, 100$-seed weight, seeds weight plot $^{-1}$ and seeds weight fad ${ }^{-1}$ in both seasons (Table 5). Planting maize plants on one side of terraces of $140 \mathrm{~cm}$ width with $60 \mathrm{~cm}$ between hills and leaving three plants/hill $\left(\mathrm{D}_{3}\right)$ and planting watermelon pulp on the other side of the terraces produced the highest number of fruits plots ${ }^{-1}$, number of seeds fruit $^{-1}$, seeds weight fruit ${ }^{-1}, 100$-seed weight, seeds weight plot $^{-1}$ and seeds weight fad ${ }^{-1}$ of watermelon pulp during the two growing seasons. However, planting maize plants on one side of terraces of $140 \mathrm{~cm}$ width with $40 \mathrm{~cm}$ between hills and leaving two plants/hill $\left(\mathrm{D}_{2}\right)$ and planting watermelon pulp on the other side of the terraces ranked secondly after aforesaid plant distribution concerning its effect on watermelon pulp growth, yield and its attributes in both growing seasons. While, using the first plant distribution $\left(\mathrm{D}_{1}\right)$, i.e., planting maize plants on one side of terraces of $140 \mathrm{~cm}$ width with $20 \mathrm{~cm}$ between hills and leaving one plant/hill and planting watermelon pulp on the other side of the terraces resulted in the lowest values of all studied watermelon pulp growth, yield and its attributes in both seasons. These increments in growth, yield and its attributes of watermelon pulp with $\mathrm{D}_{3}$ plant distribution may be ascribed to that plant distribution have great importance in the interception and efficiency of conversion of the photosynthetically active radiation intercepted by the canopy into seeds (Ogundari \& Ojo, 2005). Also, these plant distributions can be reduce the use efficiency of water, light and nutrients by plants (Moyin-Jesu, 2012).

The effect of mineral nitrogen fertilizer for maize and the recommended dose for watermelon pulp had significant effects on watermelon pulp growth, yield and its attributes (number of fruits plots $^{-1}$, number of seeds fruit ${ }^{-1}$, seeds weight fruit ${ }^{-1}, 100$-seed weight, seeds weight plot $^{-1}$ and seeds weight fad $^{-1}$ ) in the two growing seasons as shown from data revealed in Table 5. It can be stated that mineral fertilizing maize plants with $75 \%$ of the recommended dose $(90 \mathrm{~kg} \mathrm{~N} / \mathrm{fad})$ and watermelon pulp with the recommended dose produced the highest values of all studied growth, yield and its attributes of watermelon pulp in both seasons. While, mineral fertilizing maize plants with 
$100 \%$ of the recommended dose $(120 \mathrm{~kg} \mathrm{~N} / \mathrm{fad})$ and watermelon pulp with the recommended dose came in the second rank with respect to these characters in both seasons.

Table 5. Effect of plant distributions and different levels of nitrogen fertilizer as well as their interactions on number of fruits plots ${ }^{-1}$, number of seeds fruit ${ }^{-1}$, seeds weight fruit ${ }^{-1}, 100$-seed weight, seeds weight plot $^{-1}$ and seeds weight fad ${ }^{-1}$ of watermelon pulp during the two summer seasons 2018 and 2019

\begin{tabular}{|c|c|c|c|c|c|c|c|c|c|c|c|c|c|}
\hline \multirow{2}{*}{\multicolumn{2}{|c|}{$\begin{array}{l}\text { Characters } \\
\text { Treatments } \\
\end{array}$}} & \multicolumn{2}{|c|}{$\begin{array}{c}\text { No. of } \\
\text { fruits plots }\end{array}$} & \multicolumn{2}{|c|}{$\begin{array}{c}\text { No. of } \\
\text { seeds fruit }^{-1}\end{array}$} & \multicolumn{2}{|c|}{$\begin{array}{c}\text { Seeds } \\
\text { weight fruit }^{-1}\end{array}$} & \multicolumn{2}{|c|}{$\begin{array}{c}\text { 100-seed } \\
\text { weight (g) }\end{array}$} & \multicolumn{2}{|c|}{$\begin{array}{l}\text { Seeds weight } \\
\quad\left(\text { g plot }^{-1}\right)\end{array}$} & \multicolumn{2}{|c|}{$\begin{array}{l}\text { Seeds weight } \\
\quad\left(\mathrm{kg} \mathrm{fad}^{-1}\right)\end{array}$} \\
\hline & & 2018 & 2019 & 2018 & 2019 & 2018 & 2019 & 2018 & 2019 & 2018 & 2019 & 2018 & 2019 \\
\hline \multicolumn{14}{|c|}{ Plant distributions: } \\
\hline $\mathbf{D}_{1}-$ & a 1 plant & $9.0 \mathrm{c}$ & $10.2 \mathrm{c}$ & $356.2 \mathrm{c}$ & $408.7 \mathrm{c}$ & $46.0 \mathrm{c}$ & $52.8 \mathrm{c}$ & $6.8 \mathrm{c}$ & $8.3 \mathrm{c}$ & $429.6 c$ & $5504 \mathrm{c}$ & $300.6 \mathrm{c}$ & $385.3 e$ \\
\hline $\mathbf{D}_{2}$ & \& 2 plants & $12.8 \mathrm{~b}$ & $15.0 \mathrm{~b}$ & $421.3 \mathrm{~b}$ & $460.0 \mathrm{~b}$ & $54.5 \mathrm{~b}$ & $61.3 \mathrm{~b}$ & $8.7 \mathrm{~b}$ & $12.2 \mathrm{~b}$ & $534.8 \mathrm{~b}$ & $611.1 b$ & $376.1 \mathrm{~b}$ & $427.8 b$ \\
\hline $\mathbf{D}_{3}-$ & \& 3 plants & $16.8 \mathrm{a}$ & $20.3 \mathrm{a}$ & $471.3 \mathrm{a}$ & $521.6 \mathrm{a}$ & $64.6 \mathrm{a}$ & $69.4 \mathrm{a}$ & $13.2 \mathrm{a}$ & $17.2 \mathrm{a}$ & $656.1 \mathrm{a}$ & $704.2 \mathrm{a}$ & $459.3 \mathrm{a}$ & 492.9a \\
\hline \multicolumn{14}{|c|}{ Nitrogen fertilizer as ratio of the recommended dose: } \\
\hline $25 \%$ & & $9.9 \mathrm{~d}$ & $12.1 \mathrm{~d}$ & $391.2 \mathrm{~d}$ & $436.3 \mathrm{~d}$ & $51.2 \mathrm{~d}$ & $57.2 \mathrm{~d}$ & $7.2 \mathrm{~d}$ & $10.0 \mathrm{~d}$ & $363.4 \mathrm{~d}$ & $469.2 \mathrm{~d}$ & $254.4 \mathrm{~d}$ & 328.5d \\
\hline $50 \%$ & & $11.8 \mathrm{c}$ & $14.1 \mathrm{c}$ & $407.8 \mathrm{c}$ & $454.7 \mathrm{c}$ & $53.3 \mathrm{c}$ & $60.3 \mathrm{c}$ & $8.8 \mathrm{c}$ & $11.5 \mathrm{c}$ & 491.1c & $555.6 \mathrm{e}$ & $346.1 \mathrm{e}$ & $388.9 \mathrm{e}$ \\
\hline $75 \%$ & & $15.8 \mathrm{a}$ & $18.1 \mathrm{a}$ & $441.3 \mathrm{a}$ & $489.3 \mathrm{a}$ & $59.0 \mathrm{a}$ & $64.7 \mathrm{a}$ & $11.8 \mathrm{a}$ & $15.2 \mathrm{a}$ & $676.2 \mathrm{a}$ & $759.2 \mathrm{a}$ & $473.4 \mathrm{a}$ & 531.5a \\
\hline 100 & & $14.0 \mathrm{~b}$ & $16.3 \mathrm{~b}$ & $424.6 \mathrm{~b}$ & $473.3 \mathrm{~b}$ & $56.7 \mathrm{~b}$ & $62.6 \mathrm{~b}$ & $10.5 \mathrm{~b}$ & $13.5 \mathrm{~b}$ & $629.7 b$ & $703.6 \mathrm{~b}$ & $440.8 \mathrm{~b}$ & $492.5 \mathrm{~b}$ \\
\hline \multicolumn{14}{|c|}{ Interaction: } \\
\hline \multirow{4}{*}{$\mathbf{D}_{1}$} & $25 \%$ & $5.7 \mathrm{~h}$ & $7.3 \mathrm{k}$ & 341.31 & $686.3 \mathrm{k}$ & $41.8 \mathrm{~g}$ & 48.31 & $4.6 \mathrm{k}$ & $6.4 \mathrm{k}$ & $285.3 \mathrm{k}$ & $410.0 \mathrm{j}$ & $199.7 \mathrm{i}$ & $287.0 \mathrm{j}$ \\
\hline & $50 \%$ & $8.3 \mathrm{~g}$ & $9.3 \mathrm{j}$ & $351.0 \mathrm{k}$ & $401.3 \mathrm{j}$ & $45.2 \mathrm{fg}$ & $51.7 \mathrm{k}$ & $6.5 \mathrm{j}$ & $7.2 \mathrm{j}$ & $397.3 \mathrm{i}$ & $510.0 \mathrm{~h}$ & $278.1 \mathrm{j}$ & 357.0h \\
\hline & $75 \%$ & $11.3 \mathrm{ef}$ & $12.7 \mathrm{~h}$ & $371.3 \mathrm{i}$ & $431.0 \mathrm{~h}$ & $49.7 \mathrm{e}$ & $56.7 \mathrm{i}$ & $8.4 \mathrm{~g}$ & $10.3 \mathrm{~h}$ & $550.0 \mathrm{f}$ & $661.7 \mathrm{e}$ & $385.0 \mathrm{f}$ & $463.2 \mathrm{e}$ \\
\hline & $100 \%$ & $10.7 \mathrm{f}$ & $11.3 \mathrm{i}$ & $361.0 \mathrm{j}$ & $416.0 \mathrm{i}$ & $47.3 \mathrm{ef}$ & $54.6 \mathrm{j}$ & $7.5 \mathrm{~h}$ & $9.1 \mathrm{i}$ & $485.0 \mathrm{~g}$ & $620.0 \mathrm{f}$ & $339.5 \mathrm{~h}$ & 434.0f \\
\hline \multirow{4}{*}{$\mathbf{D}_{2}$} & $25 \%$ & $10.7 \mathrm{f}$ & $11.7 \mathrm{i}$ & $391.3 \mathrm{~h}$ & $431.0 \mathrm{~h}$ & $50.1 \mathrm{e}$ & $57.6 \mathrm{~h}$ & $6.5 \mathrm{j}$ & $9.2 \mathrm{i}$ & $350.0 \mathrm{j}$ & $463.3 \mathrm{i}$ & $245.0 \mathrm{k}$ & $324.3 i$ \\
\hline & $50 \%$ & $11.7 \mathrm{e}$ & $13.7 \mathrm{~g}$ & $411.0 \mathrm{~g}$ & $451.3 \mathrm{~g}$ & $53.7 \mathrm{~d}$ & $60.7 \mathrm{~g}$ & $7.4 \mathrm{i}$ & $11.1 \mathrm{~g}$ & $499.0 \mathrm{~g}$ & $543.3 \mathrm{~g}$ & $356.3 \mathrm{~g}$ & $380.3 \mathrm{~g}$ \\
\hline & $75 \%$ & $15.3 \mathrm{c}$ & $18.3 \mathrm{~d}$ & $451.3 \mathrm{~d}$ & $486.0 \mathrm{e}$ & $58.2 \mathrm{bc}$ & $64.7 \mathrm{e}$ & $11.4 \mathrm{~d}$ & $15.2 \mathrm{~d}$ & $669.7 \mathrm{c}$ & $731.3 \mathrm{c}$ & $468.8 \mathrm{c}$ & $511.9 \mathrm{c}$ \\
\hline & $100 \%$ & $13.3 \mathrm{~d}$ & $16.3 \mathrm{f}$ & $431.3 \mathrm{f}$ & $471.7 \mathrm{f}$ & $56.0 \mathrm{~cd}$ & $62.3 \mathrm{f}$ & $9.4 \mathrm{f}$ & $13.2 \mathrm{f}$ & $620.7 \mathrm{~d}$ & $706.3 d$ & $434.5 \mathrm{~d}$ & 494.4d \\
\hline \multirow{4}{*}{$\mathbf{D}_{3}$} & $25 \%$ & $13.3 \mathrm{~d}$ & $17.3 \mathrm{e}$ & $441.0 \mathrm{e}$ & $491.7 \mathrm{~d}$ & $61.6 \mathrm{~b}$ & $65.7 \mathrm{~d}$ & $10.4 \mathrm{e}$ & $14.3 \mathrm{e}$ & $455.0 \mathrm{~h}$ & $534.3 \mathrm{~g}$ & $318.5 \mathrm{i}$ & 374.0g \\
\hline & $50 \%$ & $15.3 \mathrm{c}$ & $19.3 \mathrm{c}$ & $461.3 \mathrm{c}$ & $511.3 \mathrm{c}$ & $61.0 \mathrm{~b}$ & $68.8 \mathrm{c}$ & $12.4 \mathrm{c}$ & $16.2 \mathrm{c}$ & $577.0 \mathrm{e}$ & $613.3 \mathrm{f}$ & $403.9 \mathrm{e}$ & $429.3 f$ \\
\hline & $75 \%$ & $20.7 \mathrm{a}$ & $23.3 \mathrm{a}$ & $501.3 \mathrm{a}$ & $551.0 \mathrm{a}$ & $69.1 \mathrm{a}$ & $72.8 \mathrm{a}$ & $15.5 \mathrm{a}$ & $20.2 \mathrm{a}$ & $809.0 \mathrm{a}$ & $884.7 \mathrm{a}$ & $566.3 \mathrm{a}$ & $619.3 a$ \\
\hline & $100 \%$ & $18.0 \mathrm{~b}$ & $21.3 \mathrm{~b}$ & $481.3 \mathrm{~b}$ & $532.3 \mathrm{~b}$ & $66.8 \mathrm{a}$ & $70.7 \mathrm{~b}$ & $14.5 \mathrm{~b}$ & $18.1 \mathrm{~b}$ & $783.3 b$ & $784.3 b$ & $548.3 b$ & 549.0 b \\
\hline \multicolumn{2}{|c|}{ Solid } & 24.0 & 25.0 & $\mathbf{5 0 0 . 0}$ & 550.0 & 65.0 & 69.0 & 19.0 & 20.0 & 900.0 & 920 & 586.0 & 650 \\
\hline
\end{tabular}

On the other hand, the lowest values of growth, yield and its attributes of watermelon pulp were resulted from mineral fertilizing maize plants with $25 \%$ of the recommended dose $(30 \mathrm{~kg} \mathrm{~N} / \mathrm{fad})$ and watermelon pulp with the recommended dose in both seasons. The increases in growth, yield and its attributes of watermelon pulp crop as a result of increasing nitrogen fertilizer level up to $90 \mathrm{~kg} \mathrm{~N} /$ fad to maize can be ascribed to various affects of nitrogen in physiological and biochemical processes in plant cells that ultimately affect the growth and development of the plant Ibrahim (2012).

Growth, yield and its attributes of watermelon pulp significantly affected by the interaction between plant distributions and nitrogen fertilizer levels in both seasons (Table 5). The highest values of number of fruits plots ${ }^{1}$, number of seeds fruit ${ }^{-1}$, seeds weight fruit ${ }^{-1}, 100$-seed weight, seeds weight plot $^{-1}$ and seeds weight fad ${ }^{-1}$ of watermelon pulp were obtained from planting maize plants on one side of terraces of $140 \mathrm{~cm}$ width with $60 \mathrm{~cm}$ between hills and leaving three plants/hill and planting watermelon pulp on the other side of the terraces besides fertilizing maize plants with $75 \%$ of the recommended dose $(90 \mathrm{~kg} \mathrm{~N} / \mathrm{fad})$ and watermelon pulp with the recommended dose in both seasons. The second best interaction treatment was using the formerly mentioned plant distribution of maize and watermelon pulp but fertilizing maize plants with $100 \%$ of the recommended dose $(120 \mathrm{~kg} \mathrm{~N} / \mathrm{fad})$ and watermelon pulp with the recommended dose in both seasons. Whereas, the lowest values of all studied growth, yield and its attributes of watermelon pulp were obtained from planting maize plants on one side of terraces of $140 \mathrm{~cm}$ width with $20 \mathrm{~cm}$ between hills and leaving one plant/hill and planting watermelon pulp on the other side of the terraces besides fertilizing maize plants with $25 \%$ of the recommended dose $(30 \mathrm{~kg} \mathrm{~N} / \mathrm{fad})$ and watermelon pulp with the recommended dose in both seasons. 


\subsection{Competitive Relationships and Yield Advantages}

As given away from data presented in Tables 6 and 7, the highest values of land equivalent ratio (LER), relative crowding coefficient (RCC), area time equivalent ratio (ATER), land equivalent coefficient (LEC), aggressivity index (AI) and monetary advantage index (MAI) were obtained from planting maize plants on one side of terraces of $140 \mathrm{~cm}$ width with $60 \mathrm{~cm}$ between hills and leaving three plants/hill and planting watermelon pulp on the other side of the terraces besides fertilizing maize plants with $75 \%$ of the recommended dose $(90 \mathrm{~kg} \mathrm{~N} / \mathrm{fad})$ and watermelon pulp with the recommended dose in both seasons.

Table 6. Effect of the interaction between maize plant distributions and different levels of nitrogen fertilizer on land equivalent ratio (LER), relative crowding coefficient (RCC), area time equivalent ratio (ATER) and land equivalent coefficient (LEC) during the two summer seasons 2018 and 2019

\begin{tabular}{|c|c|c|c|c|c|c|c|c|c|}
\hline \multirow{2}{*}{$\begin{array}{l}\text { Treatments } \\
\text { Plant } \\
\text { distributions } \\
\end{array}$} & \multirow[b]{2}{*}{$\begin{array}{l}\text { Nitrogen } \\
\text { levels }\end{array}$} & \multicolumn{2}{|c|}{$\begin{array}{l}\text { Land equivalent } \\
\text { ratio (LER) }\end{array}$} & \multicolumn{2}{|c|}{$\begin{array}{l}\text { Relative crowding } \\
\text { coefficient (RCC) }\end{array}$} & \multicolumn{2}{|c|}{$\begin{array}{c}\text { Area time } \\
\text { equivalent } \\
\text { ratio (ATER) }\end{array}$} & \multicolumn{2}{|c|}{$\begin{array}{l}\text { Land equivalent } \\
\text { coefficient (LEC) }\end{array}$} \\
\hline & & $\begin{array}{l}2018 \\
\text { RYm+RYw }\end{array}$ & $\begin{array}{l}2019 \\
\text { RYm+RYw }\end{array}$ & 2018 & 2019 & 2018 & 2019 & $\begin{array}{l}2018 \\
\text { RYm } \times R Y w\end{array}$ & $\begin{array}{l}2019 \\
\text { RYm } \times \text { RYw }\end{array}$ \\
\hline \multirow{4}{*}{$\begin{array}{l}D_{1}-20 \mathrm{~cm} \\
\& 1 \text { plant }\end{array}$} & $25 \%$ & $\begin{array}{l}0.486+0.340 \\
=0.826\end{array}$ & $\begin{array}{l}0.490+0.441 \\
=0.931\end{array}$ & $\begin{array}{l}0.464 \times 1.049 \\
=0.487\end{array}$ & $\begin{array}{l}0.472 \times 1.57 \\
=0.740\end{array}$ & 0.66 & 0.75 & $\begin{array}{l}0.468 \times 0.340 \\
=0.160\end{array}$ & $\begin{array}{l}0.490 \times 0.440 \\
=0.210\end{array}$ \\
\hline & $50 \%$ & $\begin{array}{l}0.526+0.474 \\
=1.010\end{array}$ & $\begin{array}{l}0.555+0.550 \\
=1.105\end{array}$ & $\begin{array}{l}0.546 \times 1.833 \\
=1.00\end{array}$ & $\begin{array}{l}0.615 \times 2.47 \\
=1.520\end{array}$ & 0.80 & 0.88 & $\begin{array}{l}0.530 \times 0.470 \\
=0.250\end{array}$ & $\begin{array}{l}0.560 \times 0.550 \\
=0.300\end{array}$ \\
\hline & $75 \%$ & $\begin{array}{l}0.571+0.657 \\
=1.228\end{array}$ & $\begin{array}{l}0.636+0.712 \\
=1.348\end{array}$ & $\begin{array}{l}0.656 \times 3.880 \\
=2.55\end{array}$ & $\begin{array}{l}0.860 \times 5.034 \\
=4.330\end{array}$ & 0.97 & 1.08 & $\begin{array}{l}0.570 \times 0.660 \\
=0.380\end{array}$ & $\begin{array}{l}0.640 \times 0.710 \\
=0.450\end{array}$ \\
\hline & $100 \%$ & $\begin{array}{l}0.567+0.579 \\
=1.176\end{array}$ & $\begin{array}{l}0.686+0.667 \\
=1.353\end{array}$ & $\begin{array}{l}0.731 \times 2.796 \\
=2.044\end{array}$ & $\begin{array}{l}1.080 \times 4.080 \\
=4.140\end{array}$ & 0.94 & 1.09 & $\begin{array}{l}0.600 \times 0.580 \\
=0.350\end{array}$ & $\begin{array}{l}0.690 \times 0.670 \\
=0.460\end{array}$ \\
\hline \multirow{4}{*}{$\begin{array}{l}D_{2}-40 \mathrm{~cm} \\
\& 2 \text { plants }\end{array}$} & $25 \%$ & $\begin{array}{l}0.433+0.418 \\
=0.850\end{array}$ & $\begin{array}{l}0.456+0.498 \\
=0.954\end{array}$ & $\begin{array}{l}0.376 \times 1.458 \\
=0.548\end{array}$ & $\begin{array}{l}0.412 \times 2.020 \\
=0.830\end{array}$ & 0.68 & 0.77 & $\begin{array}{l}0.430 \times 0.420 \\
=0.180\end{array}$ & $\begin{array}{l}0.460 \times 0.500 \\
=0.230\end{array}$ \\
\hline & $50 \%$ & $\begin{array}{l}0.469+0.608 \\
=1.070\end{array}$ & $\begin{array}{l}0.525+0.585 \\
=1.100\end{array}$ & $\begin{array}{l}0.435 \times 3.149 \\
=1.369\end{array}$ & $\begin{array}{l}0.540 \times 2.862 \\
=1.55\end{array}$ & 0.85 & 0.89 & $\begin{array}{l}0.470 \times 0.610 \\
=0.287\end{array}$ & $\begin{array}{l}0.520 \times 0.590 \\
=0.300\end{array}$ \\
\hline & $75 \%$ & $\begin{array}{l}0.545+0.799 \\
=1.344\end{array}$ & $\begin{array}{l}0.590+0.787 \\
=1.377\end{array}$ & $\begin{array}{l}0.505 \times 8.060 \\
=4.07\end{array}$ & $\begin{array}{l}0.710 \times 7.530 \\
=5.340\end{array}$ & 1.06 & 1.10 & $\begin{array}{l}0.550 \times 0.800 \\
=0.440\end{array}$ & $\begin{array}{l}0.590 \times 0.790 \\
=0.470\end{array}$ \\
\hline & $100 \%$ & $\begin{array}{l}0.523+0.741 \\
=1.264\end{array}$ & $\begin{array}{l}0.576+0.760 \\
=1.336\end{array}$ & $\begin{array}{l}0.539 \times 5.822 \\
=3.138\end{array}$ & $\begin{array}{l}0.670 \times 6.451 \\
=4.320\end{array}$ & 1.0 & 1.07 & $\begin{array}{l}0.520 \times 0.740 \\
=0.380\end{array}$ & $\begin{array}{l}0.580 \times 0.760 \\
=0.440\end{array}$ \\
\hline \multirow{4}{*}{$\begin{array}{l}D_{3}-60 \mathrm{~cm} \\
\& 3 \text { plants }\end{array}$} & $25 \%$ & $\begin{array}{l}0.410+0.544 \\
=0.954\end{array}$ & $\begin{array}{l}0.400+0.575 \\
=0.975\end{array}$ & $\begin{array}{l}0.343 \times 2.417 \\
=0.829\end{array}$ & $\begin{array}{l}0.345 \times 2.751 \\
=0.949\end{array}$ & 0.76 & 0.78 & $\begin{array}{l}0.410 \times 0.540 \\
=0.220\end{array}$ & $\begin{array}{l}0.400 \times 0.580 \\
=0.320\end{array}$ \\
\hline & $50 \%$ & $\begin{array}{l}0.454+0.689 \\
=1.143\end{array}$ & $\begin{array}{l}0.466+0.660 \\
=1.126\end{array}$ & $\begin{array}{l}0.410 \times 4.470 \\
=1.83\end{array}$ & $\begin{array}{l}0.446 \times 3.949 \\
=1.761\end{array}$ & 0.90 & 0.90 & $\begin{array}{l}0.450 \times 0.690 \\
=0.310\end{array}$ & $\begin{array}{l}0.470 \times 0.660 \\
=0.310\end{array}$ \\
\hline & $75 \%$ & $\begin{array}{l}0.529+0.966 \\
=1.495\end{array}$ & $\begin{array}{l}0.596+0.952 \\
=1.548\end{array}$ & $\begin{array}{l}0.552 \times 58.360 \\
=32.22\end{array}$ & $\begin{array}{l}0.730 \times 40.95 \\
=29.90\end{array}$ & 1.18 & 1.23 & $\begin{array}{l}0.530 \times 0.970 \\
=0.510\end{array}$ & $\begin{array}{l}0.600 \times 0.950 \\
=0.750\end{array}$ \\
\hline & $100 \%$ & $\begin{array}{l}0.477+0.936 \\
=1.413\end{array}$ & $\begin{array}{l}0.531+0.844 \\
=1.375\end{array}$ & $\begin{array}{l}0.450 \times 56.500 \\
=25.42\end{array}$ & $\begin{array}{l}0.560 \times 11.036 \\
=6.180\end{array}$ & 1.12 & 1.10 & $\begin{array}{l}0.480 \times 0.940 \\
=0.450\end{array}$ & $\begin{array}{l}0.530 \times 0.840 \\
=0.440\end{array}$ \\
\hline
\end{tabular}

Note. RYw: Relative yield watermelon; RYm: Relative yield maize. 
Table 7. Effect of the interaction between maize plant distributions and different levels of nitrogen fertilizer on aggressivity index (AI) and monetary advantage index (MAI) during the two summer seasons 2018 and 2019

\begin{tabular}{|c|c|c|c|c|c|c|c|}
\hline \multicolumn{2}{|l|}{ Treatments } & \multicolumn{4}{|c|}{ Aggressivity index (AI) } & \multicolumn{2}{|c|}{ Monetary advantage index (MAI) } \\
\hline \multirow[b]{2}{*}{ Plant distributions } & \multirow[b]{2}{*}{ Nitrogen levels } & \multicolumn{2}{|c|}{2017} & \multicolumn{2}{|c|}{2018} & \multirow[b]{2}{*}{2017} & \multirow[b]{2}{*}{2018} \\
\hline & & $\begin{array}{l}\text { Maize } \\
\text { AM }\end{array}$ & $\begin{array}{l}\text { Watermelon } \\
\text { AW }\end{array}$ & $\begin{array}{l}\text { Maize } \\
\text { AM }\end{array}$ & $\begin{array}{l}\text { Watermelon } \\
\text { AW }\end{array}$ & & \\
\hline \multirow{4}{*}{$D_{1}-20 \mathrm{~cm} \& 1$ plant } & $25 \%$ & -0.308 & +0.308 & -0.600 & +0.600 & -2456.000 & -1057.150 \\
\hline & $50 \%$ & -0.560 & +0.560 & -0.835 & +0.835 & +1403.930 & +1518.181 \\
\hline & $75 \%$ & -1.130 & +1.130 & -1.200 & +1.200 & +3245.472 & +5200.223 \\
\hline & $100 \%$ & -0.860 & +0.860 & -0.990 & +0.990 & +2499.693 & +5303.148 \\
\hline \multirow{4}{*}{$D_{2}-40 \mathrm{~cm} \& 2$ plants } & $25 \%$ & -0.620 & +0.620 & -0.380 & +0.380 & -2132.640 & -762.763 \\
\hline & $50 \%$ & -1.140 & +1.140 & -0.995 & +0.995 & +1004.690 & +1527.500 \\
\hline & $75 \%$ & -1.609 & +1.609 & -1.504 & +1.504 & +4875.447 & +6589.762 \\
\hline & $100 \%$ & -1.466 & +1.466 & -1.440 & +1.440 & +3722.539 & +5070.338 \\
\hline \multirow{4}{*}{$D_{3}-60 \mathrm{~cm} \& 3$ plants } & $25 \%$ & -1.033 & +1.033 & -1.139 & +1.139 & -7164.473 & -464.536 \\
\hline & $50 \%$ & -1.400 & +1.400 & -1.304 & +1.304 & +2045.850 & +1850.089 \\
\hline & $75 \%$ & -2.139 & +2.139 & -1.996 & +1.996 & +7094.723 & +8356.850 \\
\hline & $100 \%$ & -2.122 & +2.122 & -1.766 & +1.766 & +5896.294 & +5714.744 \\
\hline
\end{tabular}

Table 8. Effect of the interaction between maize plant distributions and different levels of nitrogen fertilizer on economic evaluation during the two summer seasons 2018 and 2019

\begin{tabular}{|c|c|c|c|c|c|c|c|c|c|c|c|}
\hline \multirow{3}{*}{$\begin{array}{l}\text { Treatments } \\
\text { Plant } \\
\text { distributions }\end{array}$} & \multirow[b]{3}{*}{$\begin{array}{l}\text { Nitrogen } \\
\text { levels }\end{array}$} & \multicolumn{10}{|c|}{ Economic evaluation } \\
\hline & & \multicolumn{5}{|c|}{2018} & \multicolumn{5}{|c|}{2019} \\
\hline & & $\begin{array}{l}\text { Actual } \\
\text { yield L.E. } \\
\text { Maize }\end{array}$ & $\begin{array}{l}\text { Actual } \\
\text { yield L.E. } \\
\text { Watermelon }\end{array}$ & $\begin{array}{l}\text { Total } \\
\text { income } \\
\text { L.E. }\end{array}$ & $\begin{array}{l}\text { Total } \\
\text { cost } \\
\text { L.E. }\end{array}$ & $\begin{array}{l}\text { Economic } \\
\text { return } \\
\text { L.E. }\end{array}$ & $\begin{array}{l}\text { Actual } \\
\text { yield L.E. } \\
\text { Maize }\end{array}$ & $\begin{array}{l}\text { Actual } \\
\text { yield L.E. } \\
\text { Watermelon }\end{array}$ & $\begin{array}{l}\text { Total } \\
\text { income } \\
\text { L.E. }\end{array}$ & $\begin{array}{l}\text { Total } \\
\text { cost } \\
\text { L.E. }\end{array}$ & $\begin{array}{l}\text { Economic } \\
\text { return } \\
\text { L.E. }\end{array}$ \\
\hline \multirow{4}{*}{$\begin{array}{l}D_{1}-20 \mathrm{~cm} \\
\& 1 \text { plant }\end{array}$} & $25 \%$ & 6670 & 4992.5 & 11662.5 & 7565 & 4097.5 & 6870 & 7175 & 14045 & 7565 & 6480 \\
\hline & $50 \%$ & 7230 & 6952.5 & 14807.5 & 7710 & 7097.5 & 7775 & 8925 & 16700 & 7710 & 8990 \\
\hline & $75 \%$ & 7855 & 9625 & 17480 & 7938 & 9542 & 8915 & 11580 & 20495 & 7938 & 12557 \\
\hline & $100 \%$ & 8215 & 8487.5 & 16702.5 & 8275 & 8427.5 & 9605 & 10850 & 20455 & 8275 & 12180 \\
\hline \multirow{4}{*}{$\begin{array}{l}D_{2}-40 \mathrm{~cm} \\
\& 2 \text { plants }\end{array}$} & $25 \%$ & 5960 & 6125 & 12085 & 7565 & 4520 & 6385 & 8107.5 & 14492.5 & 7565 & 6927.5 \\
\hline & $50 \%$ & 6450 & 8907.5 & 15357.5 & 7710 & 7647.5 & 7295 & 9507.5 & 16802.5 & 7710 & 9092.5 \\
\hline & $75 \%$ & 7495 & 11700 & 19195 & 7938 & 11257 & 8270 & 12797.5 & 21067.5 & 7938 & 13129.5 \\
\hline & $100 \%$ & 7190 & 10850 & 18040 & 8275 & 9765 & 8075 & 12360 & 20435 & 8275 & 12160 \\
\hline \multirow{4}{*}{$\begin{array}{l}D_{3}-60 \mathrm{~cm} \\
\& 3 \text { plants }\end{array}$} & $25 \%$ & 5650 & 7962.5 & 13612.5 & 7565 & 6047.5 & 5670 & 9350 & 15020 & 7565 & 7455 \\
\hline & $50 \%$ & 6255 & 10097.5 & 16352.5 & 7710 & 8642.5 & 6535 & 10732.5 & 17217.5 & 7710 & 9507.5 \\
\hline & $75 \%$ & 7270 & 14157.5 & 21427.5 & 7938 & 13489.5 & 8350 & 15482.5 & 23832.5 & 7938 & 15894.5 \\
\hline & $100 \%$ & 6570 & 13707.5 & 20277.5 & 8275 & 12002.5 & 7435 & 13725 & 21160 & 8275 & 12885 \\
\hline \multicolumn{2}{|l|}{ Solid maize } & - & - & 13750 & 6300 & 7450 & - & - & 14650 & 6300 & 8350 \\
\hline \multicolumn{2}{|c|}{ Solid watermelon } & - & - & 14000 & 6800 & 7200 & - & - & 16250 & 6800 & 9450 \\
\hline
\end{tabular}

Nevertheless, using $\mathrm{D}_{3}$ plant distribution and fertilizing maize plants with $100 \%$ of the recommended dose (120 $\mathrm{kg} \mathrm{N} / \mathrm{fad}$ ) and watermelon pulp with the recommended dose came in the second rank regarding the aforementioned competitive relationships traits in both seasons. While, the lowest values of LER, RCC, ATER, LEC and AI were recorded by planting maize plants on one side of terraces of $140 \mathrm{~cm}$ width with $20 \mathrm{~cm}$ between hills and leaving one plant/hill and planting watermelon pulp on the other side of the terraces besides fertilizing maize plants with $25 \%$ of the recommended dose $(30 \mathrm{~kg} \mathrm{~N} / \mathrm{fad})$ and watermelon pulp with the recommended dose in both seasons.

Concerning the economic evaluation of the interaction between maize plant distributions and different levels of nitrogen fertilizer during the two summer seasons 2018 and 2019 , the data obtainable in Table 8 clear that the highest values of actual yield (L.E.) of watermelon, total income (L.E.) and economic return (L.E.) were resulted from planting maize plants on one side of terraces of $140 \mathrm{~cm}$ width with $60 \mathrm{~cm}$ between hills and leaving three plants/hill and planting watermelon pulp on the other side of the terraces besides fertilizing maize plants with $75 \%$ of the recommended dose $(90 \mathrm{~kg} \mathrm{~N} / \mathrm{fad})$ and watermelon pulp with the recommended dose in both seasons. 
However, the highest values of actual yield (L.E.) of maize and total cost (L.E.) were obtained from using $\mathrm{D}_{1}$ plant distribution and fertilizing maize plants with $100 \%$ of the recommended dose $(120 \mathrm{~kg} \mathrm{~N} / \mathrm{fad})$ and watermelon pulp with the recommended dose came in both seasons. While, the lowest values of actual yield (L.E.) of watermelon, total income (L.E.) and economic return (L.E.) were recorded by planting maize plants on one side of terraces of $140 \mathrm{~cm}$ width with $20 \mathrm{~cm}$ between hills and leaving one plant/hill and planting watermelon pulp on the other side of the terraces besides fertilizing maize plants with $25 \%$ of the recommended dose (30 kg N/fad) and watermelon pulp with the recommended dose in both seasons. Though, the lowest values of actual yield (L.E.) of maize and total cost (L.E.) were obtained from using $\mathrm{D}_{3}$ plant distribution and fertilizing maize plants with $25 \%$ of the recommended dose $(30 \mathrm{~kg} \mathrm{~N} / \mathrm{fad})$ and watermelon pulp with the recommended dose came in both seasons.

From the obtained results of this study, it can be concluded that the maximum values of 100-kernel weight and grain yield $\mathrm{fad}^{-1}$ of maize were obtained from planting maize plants on $20 \mathrm{~cm}$ between hills and leaving one plant/hill in addition fertilizing with $120 \mathrm{~kg} \mathrm{~N} \mathrm{fad}^{-1}$. while the lowest values of all studied growth yield and its attributes of watermelon pulp were found the highest values of growth, yield and its attributes of watermelon pulp and competitive relationships and yield advantages, i.e., land equivalent ratio (LER), relative crowding coefficient (RCC), area time equivalent ratio (ATER), land equivalent coefficient (LEC), aggressively index (AI), monetary advantage index (MAI), actual yield (L.E.) of watermelon, total income (L.E.) and economic return (L.E.) were obtained from planting maize on $60 \mathrm{~cm}$ between hills and leaving three plants/hill and planting watermelon pulp on the other side of the terraces besides fertilizing maize plants with $90 \mathrm{~kg} \mathrm{~N} / \mathrm{fad}$ and watermelon pulp with the recommended dose under the climate conditions of El-Gharbia Governorate, Egypt.

\section{References}

Adetiloye, P. O., Ezedinma, F. O. C., \& Okigbo, B. N. (1983). A land equivalent coefficient concept for the evaluation of competitive and productive interceptions on simple complex mixture. Ecol. Modelling., 19, 27-39. https://doi.org/10.1016/0304-3800(83)90068-6

Attia, A.N., El-Moursy, S. A., Said, E. M., Seadh, S. E., \& El-Azab, A. A. S. (2012). Response of maize growth to organic and foliar fertilization under nitrogen fertilizer levels. J. Plant Production, Mansoura Univ., 3(6), 1063-1074. https://doi.org/10.21608/jpp.2012.84283

Bruin, J. L., \& Pedersen, P. (2008). Effect of row spacing and seeding rate on soybean yield. Agron. J., 100(3), 704-710. https://doi.org/10.2134/agronj2007.0106

Chim, B. K., Omara, P., Macnack, N., Mullock, J., Dhital, S., \& Raun, W. (2014). Effect of seed distribution and population on maize (Zea mays L.) grain yield. Intern. J. of Agron., 2014, Article ID 125258. https://doi.org/ $10.1155 / 2014 / 125258$

De-Wit, C. T. (1960). Intercropping its importance and research needs. Part 1. Competition and yield advantages. Field Crop Abst., 32, 1-10.

Doerge, T., Hall, T., \& Gardner, D. (2002). New research confirms benefits of improved plant spacing in corn. Crop Insights, 12(2).

Duncan, D. B. (1955). Multiple range and multiple F test. Biometrics, 11, 1-42. https://doi.org/10.2307/3001478

Duncan, W. G. (1984). A theory to explain the relationship between corn populations and grain yield. Crop Sci., 24, 1141-1145. https://doi.org/10.2135/cropsci1984.0011183X002400060032x

El-Naggar, N. Z. A., Mohamed, M. A., Mowafy, S. A., \& Abd El-Hameed, I. M. (2012). Effect of FYM and N fertilizer on yield and land use efficiency of maize-soybean intercropping. J. Plant Production, Mansoura Univ., 3(5), 729-746. https://doi.org/10.21608/jpp.2012.84216

Gomez, K. N., \& Gomez, A. A. (1984). Statistical procedures for agricultural research (2nd ed., p. 68). John Wiley and Sons, New York.

Hafez, E. M., \& Abdelaal, Kh. A. A. (2015). Impact of nitrogen fertilization levels on morphophysiological characters and yield quality of some maize hybrids (Zea mays L.). Egypt. J. Agron., 37(1), 35-48. https://doi.org/10.21608/agro.2015.62

Hiebsch, C. K., \& Mc-Collum, R. E. (1987). Area $\times$ time equivalency ratio: a method of evaluating the productivity of intercrops. Agron. J., 79, 15-22. https://doi.org/10.2134/agronj1987.00021962007900010004x

Hussein, S. M. A. (2005). Optimizing utilization of nitrogen fertilizer under some intercropping systems of groundnut and maize in sandy soil. J. Agric. Sci., Mansoura Univ., 30(9), 4979-4989. 
Ibrahim, E. A. (2012). Effect of different levels of water stress and humic acid application on yield, its components and genotypic stability of some new lines of gurma watermelon (Citrullus Colocynthoides). J. Plant Production, Mansoura Univ., 3(10), 2625-2634. https://doi.org/10.21608/jpp.2012.85008

Jackson, M. L. (1967). Soil Chemical Analysis (pp. 144-197). Printic Hall of India, New Delhi.

Jiang, C., Ren, X., Wang, H., Lu, D., Zu, C., \& Wang, S. (2019). Optimal nitrogen application rates of one-time root zone fertilization and the effect of reducing nitrogen application on summer maize. Sustainability, 11, 2979. https://doi.org/10.3390/su11102979

Lomer, A. M., Ali-zadeh, V., \& Chogan, R. (2019). Assessing dry matter accumulation in different parts of maize hybrid in different amounts of nitrogen and amino-acid. J. Mater. Environ. Sci., 10(2), 132-140.

Mattera, J., Romero, L. A., Cuatrín, A. L., Cornaglia, P. S., \& Grimoldi, A. A. (2013). Yield components, light interception and radiation use efficiency of lucerne (Medicago sativa L.) in response to row spacing. European J. of Agron., 45, 87-95. https://doi.org/10.1016/j.eja.2012.10.008

Mc-Gillchrist, C. A. (1965). Analysis of competition experiments. Biometrics, 21, 975-985. https://doi.org/ $10.2307 / 2528258$

Moyin-Jesu, E. L. (2012). Comparative evaluation of modified neem leaf, neem leaf and woodash extracts on soil fertility improvement, growth and yield of maize (Zea mays L.) and watermelon (Citullus lanatus) (Sole and intercrop). Agric. Sci., 3(1), 90-97. https://doi.org/10.4236/as.2012.31012

Ogundari, K., \& Ojo, S. O. (2005). The determinants of technical efficient in mixed crop production in Nigeria stochastic parametic approach. Applied Trop Agric., 10, 3-9.

Page, A. L. (1982). Methods of soil analysis, Part 2, chemical and microbical properties (2nd ed.). American Society of Agronomy, Soil Sci. of Amer. Inc. Madison Wisconsin, USA.

Sangoi, L., Schmitt, A., Vieira, J., Picoli, J., Souza, G. J., Casa, R. T., ... Horn, D. (2012). Variabilidade na distribuição espacial de plantas na linha e rendimento de grãos de milho. Revista Brasileira de Milho e Sorgo, 11(3), 268-277. https://doi.org/10.18512/1980-6477

Schimandeiro, A., Weirich-Neto, P. H., Gimenez, L. M., Colet, M. J., \& Garbunio, P. W. (2006). Distribuição longitudinal de plantas de milho (Zea mays L.) na região dos Campos Gerais, Paraná. Ciência Rural, 36, 977-980. https://doi.org/10.1590/S0103-84782006000300040

Sgarbossa, J., da Silva, D. R. O., Elli, E. F., Schwerz, F., Caron, B. O., Schmidt, D., .. Medeiros, S. L. P. (2018). Changes in the spatial distribution of maize plants affect solar radiation use efficiency. Australian J. Crop Sci., 12(10), 1609-1615. https://doi.org/10.21475/ajcs.18.12.10.p1187

Shams, A. S., El-Debaby, A. S., Roshdy, A., \& Kamel, A. S. (2012). Effect of Maize Plants Distribution and Nitrogen Fertilization Levels in Peanut-Maize Intercrop. Egypt. J. Agron., 34(1), 39-52. https://doi.org/ 10.21608/agro.2012.109

Sherif, S. A., Zohry, A. A., \& Ibrahim, S. T. (2005). Effect of planting dates and densities of maize intercropped with groundnut on growth, yield and yield components of both crops. Arab Univ. J. Agric. Sci., Ain Shams Univ., 13(3), 771-791. https://doi.org/10.21608/ajs.2005.15295

Shrestha, J., Chaudhary, A., \& Pokhrel, D. (2018). Application of nitrogen fertilizer in maize in Southern Asia: A review. Peruvian J. of Agron., 2(2), 22-26. https://doi.org/10.21704/pja.v2i2.1201

Silva, F. H., da Cunha, P. C. R., Almeida, A. C. S., Araújo, L. S., Jakelaitis, A., \& da Silveira, P. M. (2015). Production components of corn as function of seed distribution along the planting row. Revista Brasileira de Engenharia Agrícolae Ambiental, 19(12), 1172-1177. https://doi.org/10.1590/1807-1929

Wade, L. J., Norris, C. P., \& Walsh, P. A. (1988). Effects of suboptimal plant density and non-uniformity in plant spacing on grain yield of rain-grown sunflower. Australian J. of Exp. Agric., 28, 617-622. https://doi.org/ 10.1071/EA9880617

Willey, R. W. (1979). Intercropping-Its importance and research needs. Part 1: Competition and yield advantages. Field Crop Abst., 32, 1-10.

Willey, R. W., \& Rao, M. R. (1980). A competitive ratio for quantifying competition between intercrops. Expl. Agric., 17, 257-264. https://doi.org/10.1017/S0014479700011613 


\section{Copyrights}

Copyright for this article is retained by the author(s), with first publication rights granted to the journal.

This is an open-access article distributed under the terms and conditions of the Creative Commons Attribution license (http://creativecommons.org/licenses/by/4.0/). 